\title{
Performance Of Commercial Strains Chicken Given Commercial Based Feed
}

\author{
D R Siregar, EMirwandhono,AH Daulay, N D Hanafi, T H Wahyuni
}

Animal Production Study Program, Faculty of Agriculture, University of North Sumatera, Medan 20155

E-mail : siregardeddy93@gmail.com

\begin{abstract}
This research aimed to conclude the best combination of commercial strain and feed on broiler's carcass. This research was conducted at Animal Husbandry Biology Laboratory, Departement of Animal Husbandry, Faculty of Agriculture, University of North Sumatera for 4 weeks from November until December 2016. This research used completely randomized design (CRD) factorial with 9 combined treatment and 3 replication. The treatment consists of A0B0, A0B1, A0B2, A1B0, A1B1, A1B2, A2B0, A2B1, A2B2. The observed parameters were cutting weight, carcass weight, and carcass percentage.

The result showed that the average weight of broiler chicken ranged from $1829,50-1929,50$ gram/head. The average of Carcass weight ranged from $1424,75-1676,50 \mathrm{gram} / \mathrm{head}$. And the average of carcass percentage ranged from $78,01 \%-87,98 \%$. This research conlude that the best combination is $\mathrm{A} 1$ and $\mathrm{B} 0$.
\end{abstract}

\section{Introduction}

In Indonesia, especially in North Sumatra, there are many companies that produce commercial feed and seeds that have different qualities so that the community is difficult to choose good quality food and seeds. The lack of community knowledge in choosing quality seeds and feed will have a negative impact on the farm cause losses [1].

Manufacturing feed and seeds issued by each company have their own strengths and weaknesses, so knowledge and accuracy is needed in choosing good quality food and seeds to determine the success of the community farming business. This factor is one of the obstacles in increasing broiler chicken population. The percentage becomes a calculation to determine the quality of broiler chicken meat. Commercial pieces that are often found are the chest, lower thighs, upper thighs, wings and back. The percentage of breasts that are expected to have a much higher value than the percentage of other commercial pieces makes it a carcass quality indicator in broiler chickens, because this part is known to be softer in meat and has a low fat content. good quality feed is needed to support a high percentage so that it benefits the farmers, currently in Indonesia there is a wide variety of commercial feed produced by manufacturers, with relatively the same price of feed but different feed quality, people are now confused by the selection of quality feed both in supporting a high percentage, it is necessary to evaluate the adequacy of the nutrition of commercial feeds of several manufacturers in order to make it easier[2]. 


\section{Materials and methods}

This research was carried out in the livestock biology laboratory of the Animal Husbandry Department of the Faculty of Agriculture, University of North Sumatra and lasted for 4 weeks from November 14 to December 14, 2016.Day old Chick (DOC) of broiler chickens is 108 tails with an initial body weight range of 40-45 g / head, drinking water, medicines, vitamins and vaccines, disinfectants namely rodalon.

The cage consists of 27 plots with a size of $1 \times 1 \times 0.5$ meters, a place to drink and feed each of 27 pieces, electric balance scales and salter scales, cage cleaning tools (sapulidi), buckets, books, stationery and calculators. The research design used was a factorial completely randomized design (CRD) factorial with 9 treatment combinations and 3 replications each replication consisting of 4 tails. The treatments studied are as follows [4].

Factor $1 \mathrm{~A} 0=$ feed PT. Charoen Pokphand (BR - 1)

$\mathrm{A} 1=$ feed PT. Gold Coin Indonesia $(\mathrm{BR}-1)$

$\mathrm{A} 2$ = feed PT. Malindo $(\mathrm{BR}-1)$

Factor $2 \mathrm{~B} 0=$ Cobb DOC PT. Charoen Pokphand

B1 = DOC Hubbord PT. Gold Coin Indonesia

$\mathrm{B} 2$ = DOC Cobb crossing and Hubbord PT. Malindo

\subsection{Life Weight}

Life weight is data obtained from the results of the final weighing after 12 hours of fasting.

\subsection{Carcass Weight}

Carcass weight is the data obtained from the results of cutting chickens minus blood, reeds, head, neck, legs, and innards.

\subsection{Percentage of carcass}

Ensminger (1980) explains that the percentage of carcass is the number of carcass weight comparisons and life weight multiplied by $100 \%$. A similar opinion was conveyed by Jull (1992) which states that the percentage of carcass weight can be obtained by dividing the weight of carcass with live weight before being cut. The percentage of carcass is determined by the amount of wasted body parts such as the head, neck, legs, viscera, hair, and blood (Jull, 1992). Further explained by Jull (1992) that the percentage of broiler body parts is 65 75\% carcass; $6.41 \%$ fur; $9-10 \%$ viscera; $9-10 \%$ blood; $7.8 \%$ head and neck and $4.40 \%$ feet. Percentage of carcass $(\%)=($ carcass weight $/$ final weight $) \times 100 \%$

\section{Result and discussion}

Table 2. Results of live weight of broiler chickens (g/head)

\begin{tabular}{ccccc}
\hline Type of & \multicolumn{3}{c}{ Seed Type } & Average \\
\cline { 2 - 4 } Feed & B0 & B1 & B2 & \\
\hline A0 & 1878.08 & 1863.00 & 1845.75 & $1862.28^{\text {tn }}$ \\
A1 & 1890.16 & 1862.16 & 1857.16 & $1869.83^{\text {tn }}$ \\
A2 & 1866.33 & 1858.00 & 1876.25 & $1866.86^{\text {tn }}$ \\
\hline Average & $1878.19^{\text {tn }}$ & $1861.06^{\text {tn }}$ & $1859.72^{\text {tn }}$ \\
\hline
\end{tabular}

Description: tn $=$ not real

In this study the highest live weight of broiler chickens was in the A1B0 treatment at 1890.16 $\mathrm{g} /$ head while the lowest live weight in A0B2 treatment was $1845.75 \mathrm{~g} /$ head. In this study the suitability of various commercial strains given commercial food has not given a 
significant effect on the live weight of broiler chickens. Life weight that is not significantly different is suspected because the protein ration content in all treatments is the same, it is possible that the nutrients in the body are used to meet basic living needs, and for the growth of organs and tissues. Scott et al. (1982) states that cut weight has a close relationship between growth and feed consumption. The higher consumption of feed will cause an increase in protein consumptionso that the growth of livestock is getting better and will increase the cut weight produced [5].

3.1. Carcass Weight

Tabel 4.Carcass weight of broiler chicken (g / tail)

\begin{tabular}{ccccc}
\hline Type of Feed & \multicolumn{3}{c}{ Seed Type } & Average \\
\cline { 2 - 4 } & B0 & B1 & B2 & \\
\hline A0 & 1491.75 & 1495.16 & 1487.66 & $1491.53^{\text {tn }}$ \\
A1 & 1494.00 & 1527.33 & 1473.50 & $1498.28^{\text {tn }}$ \\
A2 & 1542.91 & 1486.25 & 1488.25 & $1505.81^{\text {tn }}$ \\
\hline Average & $1509.56^{\text {t }}$ & $1502.92^{\text {tn }}$ & $1483.14^{\text {tn }}$ & \\
\hline
\end{tabular}

Description: $\mathrm{tn}=$ not real

The results of the analysis of diversity in the suitability of various commercial strains given commercial feed gave an effect which was not significantly different on the carcass weight of broiler chickens. The highest average carcass weight obtained in this study was in the A1B0 treatment of $1542.91 \mathrm{~g} / \mathrm{head}$, while the lowest carcass weight was in the A1B2 treatment $1473.50 \mathrm{~g} / \mathrm{head}$. There is a decrease after being carcass due to a reduction in the amount of blood and non carcass weight during cutting. Treatment that does not significantly affect the weight of life will also affect the carcass weight. According to Resnawati and Hardjoworo (1976), carcass weight is directly related to life weight. Haysedan Marion (1973) stated that the carcass weight produced was influenced by several factors, namely age, sex, life weight, size and body conformation, fat, and strains maintained. In this study the ration had the same nutrient content which was only different in the addition of feed in each treatment, so that it was probable that the same nutrient content caused almost uniform carcass weight [6].

\subsection{Percentage of Carcass}

Table 6. Weight percentage of broiler chicken carcasses

\begin{tabular}{ccccc}
\hline Type of & \multicolumn{3}{c}{ Seed Type } & Average \\
\cline { 2 - 4 } Feed & B0 & B1 & B2 & \\
\hline A0 & 79.42 & 80.24 & 80.59 & $80.37^{\text {tn }}$ \\
A1 & 79.02 & 81.95 & 79.34 & $80.71^{\text {tn }}$ \\
A2 & 82.66 & 79.93 & 79.31 & $79.74^{\text {tn }}$ \\
\hline Average & $80.08^{\text {tn }}$ & $80.10^{\text {tn }}$ & $80.64^{\text {tn }}$ & \\
\hline
\end{tabular}

Description: $\mathrm{tn}=$ not real

One factor that influences the percentage of broiler chicken carcass is the percentage of live weight. The percentage of carcass is the ratio of carcass weight to life weight, so that a large life weight will be followed by a large carcass weight and vice versa (Soeparno, 1994). The combination of commercial strains and commercial feed does not have a significant effect on the percentage of carcass [7]. 
The highest percentage of broiler chicken carcasses was A2B 0 treatment at $82.66 \%$, while the lowest percentage of carcass was in A1B0 treatment at $79.02 \%$ of life weight. This is higher than the results of the research of Pesti and Bakali (1997) which obtained the percentage of broiler carcasses ranging from $60.52 \%-69.91 \%$ of the live weight and research of Dewi (2007) which provided a commercial ration obtained $63.79 \%-67,78 \%$ of life weight [8].

\section{Conclusions}

The type of feed does not have an effect on increasing the cut weight, carcass weight and carcass percentage. This means that the use of feed from PT. Charoen, feed PT. Gold Coin Indonesia, feed PT. Malindo has no influence on the research parameters. Seed types have no effect to increase the weight of the cut, carcass weight and carcass percentage.

The interaction of the type of feed and the type of seedlings did not have an effect on increasing the cut weight, carcass weight and carcass percentage.

\section{References}

[1] Atmomarsono,UdanSuprijatna,E, Kartasudjana,R.(2005) Ilmudasarternakunggas.(edisikesatu).Jakarta:PenebarS wadaya.

[2] Berg, R. T. and Butterfield, R. M, 1972. New concepts in Cattle Growth. AGC Sydney, Australia.

[3] Dama. 2014. PengaruhProduksiKarkasAyamBroliler Yang DiberiPakanSuplementasiLimbahRestoMasakan Padang DenganKandungan Protein Yang Berbeda.Program StudiPeternakanUniversitasTribhuwanaTunggade wi

[4] Hanifah A., 2010. TaksonomiAyam. FakultasPertanianJurusanPeternakan UNS.

[5] Ketaren, S., 1986. PengantarTeknologiLemakdanMinyakPangan. UI-Press, Jakarta.

[6] Mulyantono B dan Isman. 2008. Bertahan di tengah krisis. Jakarta: Agro MediaPustaka

[7] Morran, E. T. and H. L. Orr. 1970. Influence of Strain on the Carcass. Poult. Sci. 49: 725-729.

[8] Murtidjo, B. A. 1987. PedomanMeramuPakanUnggas. Kanisius, Yogyakarta.

[9] Murtidjo, B. A. 2003. PedomanBeternak Ayam Broiler. Kanisius, Yogyakarta.

[10] Presdi,

H. 2001. pengaruhPemberianTepungBuluAyamdalamRansum TerhadapPersentase Karkas Ayam Buras Umur 6Minggu. SkripsiJurusanPeternakanFakultasPertanianUniversitas Sumatera Utara, Medan. 